\title{
Challenges and Opportunities for Collegial Governance at Canadian Universities: Reflections on a Survey of Academic Senates
}

Lea Pennock

University of Saskatchewan

Glen A. Jones

Ontario Institute for Studies in Education, University of Toronto

Jeff M. Leclerc

University of Manitoba

Sharon X. Li

Ontario Institute for Studies in Education, University of Toronto

\begin{abstract}
Following the design of a similar study in 2000, the authors conducted a study of university senates (academic councils) to assess the current state of academic governance in Canada's universities. An earlier paper presented and analyzed the data that were gathered about senate size, composition, structure, legislative authority, and work, and about structural and governance changes to senates in the intervening decade. The current paper focuses on themes arising from responses to the 2012 survey's open-ended questions, highlighting key findings. Significant findings relate to a sizeable discrepancy between senate members' perceptions of the importance of effective academic oversight and their success at achieving this. Suggested reforms include: reviewing and improving senate performance; fostering a culture of trust and respect among and within governing bodies; clarifying spheres of authority and accountability; and promoting the importance of collegial governance and oversight within the institution.
\end{abstract}




\section{Résumé}

Des suites d'une étude semblable réalisée en l'an 2000, les auteurs de cet article ont mené une étude sur les conseils académiques afin d'évaluer l'état actuel de leur gouvernance dans les universités canadiennes. Un article antérieur avait analysé des données sur la taille, la composition, la structure, le cadre légal, le cadre de travail ainsi que les changements de structure et de gouvernance des conseils de la décennie. Le présent article se penche sur les thèmes soulevés dans les réponses ouvertes du questionnaire. Les constats les plus révélateurs traitent de l'écart important entre la perception des membres du conseil quant à l'importance d'une surveillance académique efficace et de la réalisation de cet idéal dans la pratique. Parmi les recommandations de réforme, on trouve le besoin de revoir et d'améliorer le rendement des membres du conseil, la nécessité de créer une culture de confiance et de respect entre les instances de gouvernance, un éclaircissement par rapport aux sphères d'autorité, ainsi que la promotion d'une gouvernance collégiale qui se charge de la surveillance au sein de l'établissement.

\section{Introduction and Research Design}

In Canada, collegial governance is expressed in a strong tradition of shared governance. Virtually every university in Canada operates, with local variations, under a bicameral system enshrined in its founding legislation or in provincial legislation. Authority for academic matters is given to an academic council (often called the senate), and authority over finances and resources rests with a governing board made up primarily of external members whose role is to represent the public interest and to exercise responsible stewardship over institutional resources. (For an introduction to Canadian governance models and terms, see Jones, 2002.) Senates in particular have not received adequate attention in higher education governance literature. As Jones, Shanahan, and Goyan (2004) observed, "most of what has been written on the topic [university governance] is not grounded in empirical research ... [and has] tended to focus on governing boards ... or on governance mechanisms associated with finance/resource allocation issues" (pp. 36-37). ${ }^{1}$ Aside from the study from which that reference is taken, the observation remains true. There have been some subsequent studies of Canadian university boards (e.g., Chan \& Richardson, 2012; Côté, Jones, \& Shapiro, 2011; Lang, 2005; Trotter, 2009) but very little research about senates. The study by Jones et al. remains the only one that looks in depth at a representative sample of Canadian senates to explore and compare their structure, membership, roles, and work.

In 2011-2012, the authors observed that while university boards of governors appeared to be paying attention to emerging governance practices, the same seemed to be less true for academic senates. In order to test this hypothesis and to see what else might have changed in the intervening decade, the authors undertook to refresh Jones et al.'s 2000 study by re-surveying the senates of Canadian universities. Like its predecessor, the 2012 survey involved two phases. The first phase sought data on the composition, organization, and role of university senates by surveying the senate secretaries of all independent degree-granting institutions in Canada with membership in the Association 
of Universities and Colleges of Canada (AUCC). Forty-one out of 84 member universities participated in the survey. The second phase involved a survey of the senate members $(\mathrm{n}=1598)$ of 20 participating institutions from across Canada, to obtain demographic data as well as information about the work, level of engagement, perceived role, and effectiveness of the senates. A total of 373 voting senate members responded; the response rate was $23 \%$. The composition of respondents to the senate survey by category (faculty members, administrators, students, staff, others) was consistent with the overall composition of senates as collected from the senate secretaries for the first phase of the study, except for a noticeably smaller representation of senior administrators (see Table 1). The questions in the 2012 survey were asked using the same words as in the 2000 study, though both phases of the later survey were augmented with additional questions addressing emerging issues and themes related to collegial governance. Quantitative data (i.e., responses to closed-ended questions) were analyzed primarily based on the reports self-generated by the online survey instruments (FluidSurveys), while qualitative data (i.e., responses to open-ended questions) were coded following the coding processes proposed by Patton (2002) to find emerging themes and patterns.

Table 1.

Composition of Senates by Membership Category as Reported by Senate Secretaries (Phase 1) and by Responses to the Senate Survey (Phase 2)

\begin{tabular}{lcc}
\hline Membership Category & Phase 1 (\%) & Phase 2 (\%) \\
\hline Faculty & 48 & 47 \\
$\begin{array}{l}\text { Senior administrators (e.g., presidents, chancellors, VPs/provosts, } \\
\text { other senior administrators) }\end{array}$ & 10 & 6 \\
Academic administrators (e.g., deans, chairs) & 17 & 20 \\
Students (e.g., undergraduate, graduate) & 16 & 15 \\
Non-academic staff & 1 & 3 \\
$\begin{array}{l}\text { Other appointments (e.g., members of affiliated/federated institu- } \\
\text { tions, members of the governing board, bargaining units' representa- } \\
\text { tives, alumni, government representatives, other appointments) }\end{array}$ & 7 & 8 \\
\hline
\end{tabular}

An earlier paper by the authors (Pennock, Jones, Leclerc, \& Li, 2015) presented and analyzed the quantitative data that were gathered about the size, composition, structure, legislative authority, and work of the senates. Comparing findings with those of the 2000 survey, the paper observed that in general, academic senates are paying closer attention to governance. This is reflected in important structural and organizational changes that have taken place over the intervening decade. For example, approximately half of senates (47\%) have revised their by-laws; $76 \%$ of respondents reported some change in their senate's committee structure; a greater percentage of senates now have an executive committee (82\% compared with $55 \% 10$ years ago); a greater percentage provide orientation materials and sessions to their members (79\% versus $62 \%$ ); satisfaction with the adequacy of orientation has improved by 50\%; and a higher proportion of members now report they are "active" in their role as senate members (77\%, up from $74 \%$ ) and informed about the university's structures (89\% compared with $74 \%$ ). 
This paper focuses on responses to the surveys' open-ended question about the issues and problems facing senates, as reported by senate secretaries (phase 1 survey) and senate members (phase 2 survey). The responses elicited some interesting insights when compared with responses to the same questions in the 2000 study. While the most pressing issues that were identified by senate secretaries in phase 1 of the 2000 study were "external" pressures related to the rapidly changing environment, including reductions in government funding, senate secretaries in 2012 were more likely to identify internal factors as issues-tension among governing bodies, or the failure of members to set aside personal agendas to make decisions in the interest of the whole, or the challenge of engaging members of the academy in governance. The responses may suggest senate secretaries have become more concerned with building the capacity of senates (and of other governing bodies) to respond to changing environments. Senate members in phase 2 of the 2012 study reported a wider range of issues, such as the encroachment of corporate governance practices, miscommunication or lack of communication among governing bodies, and dysfunctional dynamics at senate meetings, among others. Respondents in both phases appeared more alert to questions of effective governance and oversight within their institutions than they were a decade ago.

The following sections of the paper, each introduced by direct quotations from respondents, analyze three broad and recurring themes that arose from the responses to the open-ended questions of both survey phases: engagement of the academy in collegial governance; the respective roles of board, senate, and administration; and senate effectiveness in its oversight role. The paper then discusses the evaluation of senate practices and raises some issues that may warrant further study. Drawing on literature about effective academic governance, the last section of the paper posits suggestions for reforms that might enhance the effectiveness of the senate as a governing body.

\section{Engagement of the Academy in Collegial Governance}

"I would say that the most important issue relating to the work of university senates in governance of the university is increasing the visibility of senate. While it certainly isn't a 'sexy' issue ... it is vital that ... THOSE WHO ARE INTERESTED ... have the opportunity to get involved."

"The average faculty member has little understanding or awareness of what senate does and why it is relevant to their day to day lives."

Despite the opportunities afforded by the academy to participate in academic oversight, lack of faculty engagement in collegial governance was a major theme in the responses to the survey. Respondents observed that senates themselves do a poor job of communicating to faculty colleagues the importance of collegial governance. Some identified apathy on the part of members of the academy as a roadblock to participation, reporting that faculty are not motivated to commit the necessary time and energy to senate work, either because they don't see it as important, or because they are simply too busy with the demands of teaching and research and the imperative to achieve tenure and promotion. It was suggested by many that the lack of engagement is particularly true for younger faculty.

These responses resonate with the observation of some earlier studies (e.g., Kennedy, 1997; Kool, 2012; Metcalfe et al., 2011). A review of the literature, as well as comments from respondents, suggest various reasons for faculty's lack of engagement. Metcalfe et al. (2011) pointed out that faculty seem to be increasingly content to leave administrative 
matters (including governance) to academic managers. This is understandable: the work of the day-to-day administration and management of the university is becoming more complex and requires specialized knowledge in fields such as law, technology, intellectual property, or risk management. New faculty have a lot on their plates-pressures to get their research programs up and running, and the added work of incorporating new media technologies into their teaching while keeping current on developments in their scholarly fields. At many institutions, faculty are actively discouraged from being involved in any kind of administration, including governance, until they have been granted tenure; this may account for the fact that three-quarters of the faculty members who responded to our senate survey were 45 years of age or older. The statistic supports the comment made by a number of respondents that universities are missing opportunities to explain to budding academics (including graduate students) that collegial governance is "part of the package"-that the dimensions of academic work include not just teaching, research, and service to the wider community but also involvement in overseeing the academic mission of the institution, a privilege as well as an obligation for a member of the professoriate.

\section{The Respective Roles of Senate, Board, and Administration}

"The administration has made whatever decisions they want to pursue, and they come to senate for a rubber stamp of those decisions, with little or no room for genuine dialogue."

"The board of governors effectively inserts itself into academic matters through the budget process."

"Senate occasionally spends too long debating issues over which it does not and should not have jurisdiction."

Of the 219 senators and 29 senate secretaries who responded to the open-ended question about problems and issues, almost a third of both groups referenced role confusion, power imbalance, or other tensions between the senate and the board, or between the senate and the administration. Many senate members expressed the view that the senate is "largely peripheral to the real decision-making and goal-setting mechanism," citing a "lack of true respect for the academic autonomy that should be afforded to the university senate independent of the governing board." One member claimed that the "authority of Senate is constantly usurped by the Board of Governors ... decisions are already made before they are actually discussed." On the other hand, the senate may at times be tempted to overreach itself. As cautioned by one senate secretary and echoed by one faculty member in the survey, it is important to "ensure that they [i.e., senates] understand the extent of their role and not drift into the responsibilities of the Board and of the Administration."

The theme of power imbalance was also prevalent in comments about the role of the senate relative to that of the administration. The notion that the senate simply rubber stamps decisions made elsewhere came up in 12 members' responses; half of these referenced rubber-stamping decisions made by senior administration. The idea of "corporatization" appeared 10 times in relation to the administration (7) and to the board of governors (3). Several respondents alluded to the "chilling effect" of administrators sitting and voting as a bloc on senate. A number of comments conveyed a perception that 
information is routinely held back or "spun" by the administration, and there was even a suggestion that the administration employed tactics of distraction to bring irrelevant matters to the senate, or engaged in false consultation to provide an illusion of faculty input. The result, according to one response, was "an us-versus-them dynamic" that erodes the effectiveness of collegial governance.

The comments about the administration related to two different spheres of administrative activity: the role of senior administrators in their management activities, and the role of senior administrators as members of the senate. In the latter category, responses showed a perception by some respondents that the administration is becoming more heavily represented on the senate, although this perception is not borne out by the numbers, which showed no statistically significant difference in senate composition over the past decade (compare the senate composition reported in Jones et al., 2004, p. 47, with that reported in Pennock et al., 2015, p. 507). With respect to senior administrators in their management role, some responses conveyed a perception that neither the senate nor the administration is always respectful of the other's legitimate governance role. Several responses suggested that the same kind of issues frequently identified in board/management role dysfunction-when the board micromanages rather than providing oversight, or when management withholds information or does "end runs" around the board's statutory authority-are also at work in the senate/administration dynamic. These comments came from both rank-and-file faculty members (some of whom reported that the administration usurps the senate's legitimate governing role) and from members of the academic administration, who reported that some senate members spend too much time wishing they could influence matters of budget and management, and not enough time overseeing the academic quality of programs and teaching. Notwithstanding the allegation by some respondents that the administration withholds information from the senate, the survey found that $75 \%$ of respondents agreed or strongly agreed that they were provided with the information they needed to make decisions as a member of the senate. The response to one of the survey's series of paired questions about what the senate should do and what the senate actually does is telling: 94\% of respondents believed that the senate should ask tough questions of senior administrators, but only a bare majority (52\% of all respondents, including $62 \%$ of administrators, $52 \%$ of faculty, and $36 \%$ of students) agreed that their senate asked tough questions of senior administrators.

The senate's relationship-or lack of relationship-with the governing board and its sometimes uneasy role with the administration is an important finding. A clear understanding of roles, responsibilities, and authority is essential to effective governance. This was one of the key principles articulated by Côté et al. (2011) in an external review commissioned by Concordia University to address issues in that university's governing structures. The reviewers cautioned that "board members, senate members, and university administrators need to clearly understand the nature and the boundaries of their roles and responsibilities in this context of shared governance within the organization" (p. 7). Whether the issues stem from ambiguity about the respective roles of senate, board, and administration, or from deliberate attempts by one of these bodies to usurp the authority of another, the Concordia review underlines the necessity for all those involved to understand that they are separately and collectively empowered by legislative authority and the law to make decisions that are in the best interest of the university and to discharge the 
academic and administrative oversight responsibilities entrusted to them. It is equally important that all of the bodies work towards the same institutional goals, and that each has a full understanding of and respect for the others' legitimate roles in pursuit of those goals.

\section{Senate Effectiveness in Its Oversight Role}

"In seven years as a senator I can only recall one debate about what we meant by academic quality, and that sank without a trace."

“.. . the Senate wastes time squabbling. .."

Half (51\%) of the senate members we surveyed in phase 2 agreed with the statement "Our senate is an effective decision-making body." This represents an improvement of $7 \%$ over the response to the same question a decade ago, but it is still discouragingly low. Two-thirds (68\%) of respondents agreed with the statement that the senate primarily approves decisions made elsewhere. It is therefore not surprising that almost a quarter of the responses to the open-ended questions reflect a sense that the senate lacks relevance or power.

There is less unanimity about the reasons for this apparent irrelevance, although it seems reasonable to draw a connection between perceived relevance and perceived effectiveness. Some comments referenced the size of the senate as being unwieldy; indeed, when senate members were asked what they believed to be an ideal size for the senate, the average size proposed was 54 members, much smaller than the actual average size ( 88 members) of the 20 senates that participated in phase 2. Other respondents pointed to a lack of diversity in membership, or over-representation by ex officio members, or a lack of adequate or sufficiently detailed information on which to base decisions--decisions that are rushed because agendas are too packed--and a disconnect between the senate's role as a deliberative body and some senate members' tendency to side-track discussion, or to treat the senate like a constituent assembly, or to toe a "party line." Some respondents complained that their senates were losing the "bigger picture" or "higher level" debate; still others talked about domination of the senate by an "old guard" who are not allowing younger faculty to bring their perspectives. There was an acknowledgement in many of the comments of how complex the issues are and how difficult it is to adequately present and assimilate all of the information needed for effective academic decision making. Many comments implied a real hunger for lively, meaningful debate. One response illustrates this:

Senate has a key role to play in university decision making, but the quality of the discussion at Senate is sometimes low. There are many reasons for this: Senate is too large to work effectively, many senators do not understand the bicameral nature of university governance, many of those on Senate do not have an in-depth understanding of the issues being discussed, the Senate view of governments and external bodies is frequently naïve. . . . There are moments when Senate exerts a very positive influence on the direction of the university, but these issues mean that this happens less often than it should.

One of the most interesting but least conclusive findings of our study was what it revealed about the relationship of the senate to the faculty councils, the deliberative bodies that exist within each of a university's various faculties. It was clear from the responses to 
questions relating to these councils that better understanding is needed about authority and roles not only across governing bodies but within the senate's own structures. At most of the responding universities, faculty councils are involved in the review and approval of academic matters within the various faculties and schools. The source of authority for these faculty councils is inconsistent: in about two-thirds of cases (63\%), their membership and role is not specified by provincial legislation, and in fully $20 \%$ of cases, there are no university constitutional documents or by-laws that further clarify the membership, roles, and/or responsibilities of the faculty councils. Senate secretaries reported that $45 \%$ of the faculty councils are constituted under the authority of the senate; others are constituted by boards or other bodies, and senate may or may not be involved in approving their by-laws and/or membership. Notwithstanding the role that faculty councils play in academic matters, only $36 \%$ of institutions reported that their faculty councils make reports to the senate, and in describing those reports, the senate secretaries used words and phrases such as "occasionally," "as needed," "from time to time," "infrequently," and "as issues arise." Given the legislated authority that senates have for academic matters, it seems there should be a more well-defined and rigorous oversight of the work of the faculty councils, and more regular reporting, as well as an examination of what the added value is or could be for senate to provide university-level oversight in approving collegial decisions or recommendations coming from the faculties.

The most striking evidence of our survey that the senate is not effectively performing its core functions comes from the responses of senate members to the series of paired "should/does" questions (see Table 2).

Table 2.

Responses to a Selection of Paired Questions Asked of Senate Members

\begin{tabular}{lcccc}
\hline A senate should/our senate does... & $\begin{array}{c}\text { Agree } \\
\text { Should } \\
(\%)\end{array}$ & $\begin{array}{c}\text { Disagree } \\
\text { Should } \\
(\%)\end{array}$ & $\begin{array}{c}\text { Agree } \\
\text { Does } \\
(\%)\end{array}$ & $\begin{array}{c}\text { Disagree } \\
\text { Does } \\
(\%)\end{array}$ \\
\hline $\begin{array}{l}\text { regularly review the performance of the university in } \\
\text { academic areas }\end{array}$ & 93 & 3 & 48 & 26 \\
$\begin{array}{l}\text { defend and protect the autonomy of the university } \\
\text { play a role in determining the future direction of the } \\
\text { university }\end{array}$ & 93 & 2 & 49 & 18 \\
$\begin{array}{l}\text { act as the final authority for approving major aca- } \\
\text { demic policies }\end{array}$ & 92 & 4 & 66 & 21 \\
$\begin{array}{l}\text { play a role in establishing research policies and stra- } \\
\text { tegic research directions }\end{array}$ & 72 & 15 & 37 & 32 \\
\begin{tabular}{l} 
periodically review its own performance \\
\hline
\end{tabular} & 94 & 2 & 26 & 44 \\
\hline
\end{tabular}

Unsurprising is the near unanimity of respondents concerning senate's legitimate and important oversight role-its responsibilities to review the performance of the university in academic areas, to be the final authority for approving academic policy, to defend and 
protect the university's autonomy, and to play a role in determining the future direction of the university-and the less unanimous but still strong sense of the senate's role in the research mission. In most provincial post-secondary legislation, the senate's central role-in fact, its raison d'être-is to oversee the academic work of the institution. Surprising is the level of doubt expressed that senates actually do these things-roughly half of respondents, in most cases, and far less than half in the case of research. This is clearly not because the matter of senate oversight of academic quality is off the radar: there were more comments on matters related to quality control, quality assurance, and academic excellence in senate members' responses to the survey's open-ended question than on any other theme. Many of these comments expressed the conviction that it is important for senates to be proactive rather than reactive-to stay focussed on the "big picture" and not simply be distracted by the details of a course senate is being asked to approve. The big picture included matters such as accessibility, academic integrity, and the broader relevance of programming to society; as one respondent said, "in short, the challenge is to maximize our contribution to building a better world!”

\section{Self-evaluation of the Senate}

In general, our research suggests that a heightened awareness by senate members of the importance of governance, particularly the importance of exercising effective oversight of institutional academic performance, has not necessarily translated into action. While the survey revealed that academic senates in Canada have adopted some measures to enhance their governance effectiveness-including by-law and membership review, committee restructuring, new member orientation, and transparency initiatives-a considerable majority do not regularly review their own performance. This gap occurs despite the fact that the tools to accomplish performance review, such as self-evaluation processes, benchmarking and measurement, risk and stakeholder analyses, and skills matrices for succession planning, are widely available and are often being used by the governing boards at the same institution. The proliferation of books and monographs about best practices in governance that are directed at the governing boards of universities is not matched by any similar body of literature for senates. For example, in May 2013, the website of the Association of Governing Boards for Colleges and Universities listed no fewer than 41 such resources under the category of "board governance for higher education institutions," but there was no such category for publications related to academic (senate) governance.

Self-evaluation processes are one way of reviewing the performance of governing bodies. As Table 2 shows, 94\% of senate member respondents agreed that a senate should regularly review its own performance. But when asked whether their senate does periodically review its own performance, only $26 \%$ of members agreed. This is an improvement compared with findings from the earlier study (in 2000, 63\% disagreed with the statement that their senate periodically reviewed its own performance; in 2012, that number was down to 44\%), but it is still a curious result, considering the importance virtually all senate respondents attached to this activity. The reasons are complex; while our study did not directly address these reasons, we suggest a few possibilities for further research.

One possible reason has to do with the natural tendency (explored by Birnbaum, 2001) of the academy to be skeptical of management "fads" and to look with suspicion on practices that appear aligned with-and therefore possibly introduced in service of-a corpo- 
rate agenda. "Corporatization" of universities is an idea that has been much discussed and written about in academic circles in recent years, both in Canada and more generally (see, for example, Amaral, Jones, \& Karseth, 2002; Austin \& Jones, 2015; Slaughter \& Leslie, 1997; Turk, 2000; Woodhouse, 2009). It was also a word that appeared often, and almost always in a negative context, in senate members' responses to our survey's open-ended question. The very fact that many new "good governance" practices have been adopted by the corporate world may be seen as a reason to resist their incursion into the academy. This resistance may also be exacerbated by the language of stakeholders and shareholders, corporations, directors, and customers to be found in the various instruments and templates that abound in the world of corporate board governance. This is language that in many ways is foreign (or anathema) to the academy. If this is indeed a reason that senates have been slow to undertake reviews of their governance processes, it is unfortunate, since our survey shows that despite the fact that (as an example) senate self-evaluation is not commonly practiced, an overwhelming majority of senate members believe that senates should regularly assess their own performance.

Another possible reason that senates are failing to evaluate their own performance is a more practical one and has to do with the size and composition of senates compared with boards. Phase 1 of our study revealed that the average size of senates in Canadian universities is 77. By contrast, the average corporate board stands at about 11 members (Spencer Stuart, 2015), though university boards tend to be larger, with 26 members on average (Chan \& Richardson, 2012). The sheer logistics of administering and analyzing self-assessment tools or conducting retreats for a body as large as the typical university senate is a barrier, and the value of corporate governance tools such as a succession plan or skills matrix, when virtually all members are either ex officio or elected, is debatable.

Given these potential obstacles to the adoption of existing and prevalent governance tools, perhaps what is needed is a "made in the academy" solution to promote and ensure effective governance. There is nothing inherently "corporate" about governing effectively or about assessing results-and in fact, the latter is something the academy should, arguably, be able to do better than anyone. Academics, as Bradshaw and Fredette (2009) point out, have been trained in divergent kinds of thinking and in challenging at a meta-level, attributes that should serve them well in carrying out the higher kinds of strategic oversight required of governing bodies:

Some of the research skills academics possess, such as textual analysis and deconstruction that reveal silences, may provide ways of moving ahead. In addition, the multiple views that scholars from different disciplines also naturally bring to the floor of the senate and the love of debate and conflict that we acquire from our training and socialization allow us real advantages over other governing bodies. How we bring these abilities, knowledge and training to the floor of the senate to create effective governance is the next step for reflection and action. (p. 131)

Whatever the reasons that the senate is not always effective, the consequences can be serious. Unless it operates as an effective governing body, a senate will have difficulty fulfilling its statutory obligation to oversee and ensure the quality of the teaching, research, and scholarship of the institution. And if it does not play that role, there is a real possibility that others will step up to fill the vacuum. The Canadian Association of University 
Teachers (CAUT) takes the position that the academic governance role might be fulfilled by collective bargaining:

Our task force has concluded we must finally recognize that university senates have not proven to be reliable and consistent vehicles through which academic staff can ensure their proper role in the academic governance of their institutions. We believe that academic staff associations must turn to collective bargaining to ensure their position in academic decision making as part of their terms and conditions of employment. (CAUT, 2009, p. 1)

Our survey uncovered no evidence of widespread agreement with the CAUT position among senate members; in fact, the responses show ambivalence about the role of faculty unions. Forty-one percent disagreed with the statement that "The role of our senate has been strengthened by the work of the faculty association/union"; $30 \%$ were neutral, and only $28 \%$ agreed. The percentages were similarly divided (37\%, 35\%, and $27 \%$ ) in response to the statement: "The influence of the faculty association on academic matters is increasing in comparison to that of our senate." In response to the question about issues facing senates, several senate secretaries mentioned unions, one observing that faculty unions are "trying to make Senate seem ineffectual." Among the senate members who mentioned the role of unions in academic governance, one was positive, one was neutral, and five were negative. It does not appear that most sitting senate members are looking to their bargaining units to supplant the collegial governance model. Nevertheless, any movement to enshrine governance matters in the clauses of collective agreements is one that bears watching.

\section{Discussion and Suggestions for Reform}

The findings of our study suggest that senates in Canadian universities have been slower than governing boards to focus attention on review and improvement of their governance arrangements. There does, however, appear to be a growing awareness, on the part of the members of senates and the university secretaries who serve them, of the need for governance reform and for monitoring and improving their effectiveness as governing bodies. Certainly the effectiveness of senate governance remains an issue for many senate members. The respondents recognized the apparent failure of many senates to regularly review the performance of the university in academic areas-in effect, to carry out their central role. The causes cited for ineffectiveness were many: size and composition of the assembly; rushed decision making based on incomplete information; overloaded agendas; apathy on the part of the broader academy; lack of awareness of the nature and importance of shared governance; and role confusion or lack of trust and respect among board, senate, and administration. These factors lead to frustration when members of senates feel that their time is being wasted, or that they are simply being asked to rubberstamp decisions that have been made in other forums. More fundamentally, senate members recognize the important roles that senates are not playing but need to play, especially oversight of academic performance and quality. The vast majority of members believe the senate should play these roles, yet fewer than half of them think that theirs does.

More than half ( $51 \%)$ of senate respondents agreed with the statement: "Our senate is an effective decision-making body"; fewer than a quarter (24\%) disagreed. These results represent an improvement from 10 years ago and suggest that senates in Canada are not 
in peril. We believe there continues to be "harmony in the design of bicameral government" (Cameron, 2002, p. 151). We agree with the observation of Bradshaw and Fredette (2009) that "despite its inefficiencies and problems, [we] have found the senate to provide an important check and balance within the institution over time" (p. 132). Nevertheless, there is clearly room for improvement in the way academic governance is operating at Canadian universities. We offer here a few suggestions, based on the results of our study, for addressing the concerns outlined above.

Our first suggestion would be to focus on areas (i) that are clearly within the legislative jurisdiction of the senates and (ii) where there is consensus. While some senate members see the size and/or composition of the senate as an impediment to effective governance, these matters are in most cases prescribed by provincial legislation and are not within the university's direct control. Seeking changes to legislation should not be ruled out but may be a longer-term project.

On the other hand, the need for senates to do a better job of reviewing their own performance and the academic performance of the institution is clearly an activity within the senate's purview, and it has the potential to lead to reforms that will, in turn, result in more appropriate committee structures, more focussed orientations, more engaged members, more relevant agenda materials, and more productive meetings. The "best practices" and the various instruments of effective governance that have been adopted by boards in recent years may or may not be well suited to the needs of senates, but the ends they serve-productive meetings, transparency in decision making, timely identification and mitigation of risks, robust measurements of performance, an informed governing body, and due diligence-can and should be met with tools that are appropriate to the senate and its mission. And who better than academics-whose expertise encompasses education and evaluation-to arrive at the "made in the academy" mechanisms for effective governance proposed earlier?

Our research also suggests that there is significant work to be done in promoting clarity, within governing bodies and in the broader university, about the respective roles of board, senate, and administration. This work should encompass not only clarifying the legitimate spheres of authority for each, but also encouraging and facilitating dialogue where mandates and interests overlap, and arriving at a common understanding among the three estates of the principles underlying effective university governance. Some excellent work has been done recently to enumerate the principles of effective university governance as part of the outcome of governance reviews at two Canadian universities. The report of the University of Toronto's Task Force on Governance (Patten, Goel, \& Charpentier, 2010) contains a good discussion of what makes university governance different from corporate governance, and lists a set of "Principles of Good Governance." The report of the External Governance Review Committee for Concordia University (Côté et al., 2011) includes a list of eight key governance principles, as well as commentary on how these play out in a university's governing structures.

The senior leadership of the university can play an important role in helping the senate to achieve and maintain effective performance in its oversight of the educational mission of the university. Too often the board and the senate operate as silos or solitudes. The university secretaries at each institution can play a helpful role here: at many institutions, this post facilitates the work of both the governing board and the senate and is in a good 
position to identify and encourage opportunities to bring these bodies together from time to time to discuss areas of mutual or overlapping concern. Some institutions have built opportunities for bridging the gap between governing bodies; mechanisms such as joint committees, regular reports from senate to the board and vice versa, joint retreats, and (within the limits prescribed by legislation) cross membership are all possibilities.

Presidents also have an important role to play in this work; at many institutions theirs is the only position included in the membership of both governing bodies, and in the vast majority of Canadian universities the president is ex officio the chair of the senate. It is reasonable to expect that presidents should devote at least the same level of energy and commitment to their engagement with senate as they do to their interactions with the board of governors, and that they and the provost should take the authority of the senate seriously. They should discuss with the senate executive how the senate can add value to recommendations coming forward through collegial governance processes at the departmental and faculty level, and ways to ensure that the senate is not bogged down in minutiae but rather is focussed on the important strategic questions facing the institution in its academic work. They need to acknowledge that the senate, like the board, has a right to expect accountability from the administration, departments, and faculties, for carrying out the policies and programs the senate has approved. They should engage the senate as partners in defending the autonomy of the university. They should also point out that this will require that the senate have, and can demonstrate to governments and others that it does have, mechanisms in place to measure and maintain academic standards and quality. They should do whatever they can to provide appropriate linkages and cultivate mutual trust, respect, and understanding between the board and the senate, and they should engage with their senates on the "big picture" issues, ensuring that there are mechanisms in place to do so. Above all, they must promote and model a culture of respect, since all the reforms in the world will not be sufficient to overcome a culture of mistrust. This was eloquently pointed out in the conclusion to the external review of Concordia University's governance arrangements:

There are, however, limits to what governance reform by itself can accomplish. Governance arrangements can never substitute for inspired and effective leadership. Colleagues and groups of colleagues must be able and willing to work together under such leadership in the context of both a shared vision and mutual respect. . . . Success ... will depend most crucially on whether the [university's] communities are committed to a civility of discourse and the giving to the "other" of the benefit of the doubt. (Côté et al., 2011, pp. 27-28)

As Bradshaw and Fredette (2009) pointed out, "university governance is potentially vibrant and robust but also characterized by potential for complicity, collusion, silencing and diversion of important debates" (p. 132). Administrators and senate members alike would do well to acknowledge this potential and to find ways to encourage what is robust while addressing, head-on, factors that undermine the legitimate role of governing bodies.

A culture of mutual respect and shared vision may go a long way towards addressing another major issue identified in our study: the difficulty of getting faculty members and students to become involved in collegial governance. Deans, department heads, and other senior academics have a role to play in encouraging newer faculty members to exercise their responsibility to participate in academic oversight. Communicating the value and 
role of the senate at every opportunity is one way to do this; even more important is to have the institution recognize in tangible ways (including consideration for promotion, tenure, and merit) that governance is a legitimate and important facet of academic work. Thompson, Constantineau, and Fallis (2005) provided some recommendations on incentives to encourage faculty participation in governance. A healthy senate is a sign of an engaged professoriate, one in which the faculty and students lead the decision making on academic matters. As Greer (2008) expressed, "the big problem is not the corporatization of the university or the dominance of the research agenda, but rather the systematic disengagement of faculty in matters where we ought to be taking the lead" (p. 3). Rather than collegial governance being, as the UK's 1985 Jarratt Report (Committee of ViceChancellors and Principals, 1985) accused, "a convenient cover for somnolence," it can and should be a vehicle for engaged citizenship within the institution.

Perhaps part of what is needed is a broader understanding of the concept of academic duty, along the lines of that advocated by Donald Kennedy. Kennedy (1997) has argued that

the last two decades have been marked by an increasing attenuation of institutional loyalty on the part of the professoriate; it is said, with some justification, that many of the most distinguished research scholars owe their primary allegiance to the invisible academy of their discipline rather than to their university. To the extent that is true, it seems likely that it can only be reversed by the sense of shared responsibility and common purpose that comes from meaningful participation in the institution's future. Surely that is a central part of academic duty, and its restoration will be vital to the re-establishment of the entente cordiale between the university and society. (p. 146)

Kennedy's call for making participation in governance part of the expectations for academic service was echoed a number of times by presenters at a recent conference organized by the Confederation of University Faculty Associations of British Columbia. The edited proceedings for the conference, entitled "Academic Governance 3.0," contained an introductory essay by Richard Kool, who summarized this consensus as follows: "Our membership in the academy . . . comes, as with citizenship, with rights and responsibilities. If academic freedom is our right, then academic governance is our responsibility" (Kool, 2012, p. 4).

\section{Summary}

As was suggested earlier, a good place to start to strengthen the academic senates of universities is to focus on where there is consensus. Our study identifies a strong consensus from all quarters-senior administrators, students, and rank-and-file faculty-that senates can do a much better job in several areas: reviewing and improving their own performance; fostering a culture of trust and respect within the senate as well as between governing bodies and with the administration; clarifying spheres of authority and accountability in the institution; and broadening the entire community's understanding of membership in the academy to include responsibility for collegial governance and oversight. 


\section{Notes}

1. Published in 2004, the study of Jones et al. was undertaken in 2000 and so is referred to throughout this paper as "the 2000 study."

2. This and subsequent quotations that follow section headings were made by senate members in response to the following open-ended question: "What, in your opinion, are the most important issues and problems related to the role and work of university senates in the context of university governance?”

\section{Acknowledgements}

The authors are grateful for the financial support provided by the University of Saskatchewan and the Ontario Research Chair in Postsecondary Education Policy and Measurement.

\section{References}

Amaral, A., Jones, G. A., \& Karseth, B. (Eds.). (2002). Governing higher education: National perspectives on institutional governance. Dordrecht, The Netherlands: Kluwer.

Austin, I., \& Jones, G. A. (2015). Governance of higher education: Global perspectives, theories and practices. New York, NY: Routledge.

Birnbaum, R. (2001). Management fads in higher education. San Francisco, CA: Jossey-Bass.

Bradshaw, P., \& Fredette, C. (2009). Academic governance of universities: Reflections of a senate chair on moving from theory to practice and back. Journal of Management Inquiry, 18(2), 123-133.

Cameron, D. M. (2002). The challenge of change: Canadian universities in the 21st century. Canadian Public Administration, 45(2), 145-174.

Canadian Association of University Teachers (CAUT). (2009). Report of the CAUT ad hoc advisory committee on governance. Ottawa, ON: Authors. Retrieved from http://www.caut.ca/docs/default-source/reports/report-of-the-caut-ad-hoc-advisorycommittee-on-governance-\%28nov-2009\%29.pdf?sfvrsn=0

Chan, Y. L., \& Richardson, A. W. (2012). Board governance in Canadian universities. Accounting Perspectives, 11(1), 31-55.

Committee of Vice-Chancellors and Principals (CVCP). (1985). Report of the steering committee for efficiency studies in universities. London, UK: Committee of ViceChancellors and Principals.

Côté, A. C., Jones, G. A., \& Shapiro, B. J. (2011). Strengthening governance at Concordia: A collective challenge. Report of the external governance review committee. Retrieved from http://www.oise.utoronto.ca/hec/UserFiles/File/Research/Papers/ ENGLISH.EGRC_REPORT.pdf

Greer, J. (2008). Teaching matters? Bridges, 6(3), 3. 
Jones, G. A. (2002). The structure of university governance in Canada: A policy network approach. In A. Amaral, G. A. Jones, \& B. Karseth (Eds.), Governing higher education: National perspectives on institutional governance (pp. 213-234). Dordrecht, The Netherlands: Kluwer.

Jones, G. A., Shanahan, T., \& Goyan, P. (2004). The academic senate and university governance in Canada. Canadian Journal of Higher Education, 34(2), 35-68.

Kennedy, D. (1997). Academic duty. Cambridge, MA: Harvard University Press.

Kool, R. (Ed.). (2012). Academic governance 3.O: What could it be? How can we get there? A conference organized by the Confederation of University Faculty Associations of British Columbia. Vancouver, BC: Confederation of University Faculty Associations of British Columbia.

Lang, D. W. (2005). Working boards in tertiary education: Lessons from three case studies. Canadian Society for the Study of Higher Education Professional File Number 25. Ottawa, ON: Canadian Society for the Study of Higher Education.

Metcalfe, A. S., Fisher, D., Gingras, Y., Jones, G. A., Rubenson, K., \& Snee, I. (2011). Canada: Perspectives on governance and management. In W. Locke, W. K. Cummings, \& D. Fisher (Eds.), Changing governance and management in higher education: The perspectives of the academy (pp. 151-174). Dordrecht, The Netherlands: Springer.

Patten, R., Goel, V., \& Charpentier, L. R. (2010). Report of the taskforce on governance. Toronto, ON: Office of the Governing Council.

Patton, M. Q. (2002). Qualitative research and evaluation methods ( $3^{\text {rd }} \mathrm{ed}$.). Thousand Oaks, CA: Sage.

Pennock, L., Jones, G. A., Leclerc, J. M., \& Li, S. X. (2015). Assessing the role and structure of academic senates in Canadian universities 2000-2012. Higher Education, $70(3), 503-518$.

Slaughter, S., \& Leslie, L. L. (1997). Academic capitalism: Politics, policies, and the entrepreneurial university. Baltimore, MD: The Johns Hopkins University Press.

Spencer Stuart. (2015). Canadian board index 2015. Retrieved from https://www. spencerstuart.com/research-and-insight/canadian-board-index-2015

Thompson, P., Constantineau, P., \& Fallis, G. (2005). Academic citizenship: An academic colleagues' working paper. Journal of Academic Ethics, 3(2), 127-142.

Trotter, L. D. (2009). Building boards: A qualitative analysis of the perceptions of the role of external governors on university governing boards (Unpublished doctoral dissertation). Simon Fraser University, Burnaby, BC.

Turk, J. L. (Ed.). (2000). The corporate campus: Commercialization and the dangers to Canada's colleges and universities. Toronto ON: James Lorimer \& Company.

Woodhouse, H. R. (2009). Selling out: Academic freedom and the corporate market. Kingston, ON: McGill-Queen's University Press. 


\section{Contact Information}

Lea Pennock

University of Saskatchewan

lea.pennock@usask.ca

After completing a PhD in English literature from Queen's University, Lea Pennock served a 30-year career in university administration in three provinces, including roles as registrar and academic dean, before becoming University Secretary at the University of Saskatchewan in 2005. In this role (from which she retired in 2013), Lea supported the university's board of governors, senate, and council, as well as pursuing research and presenting in the areas of higher education governance and policy. Since retiring, she has been active on several boards, including the Canadian University Boards Association and the board of United Way of Saskatoon and Area.

Glen A. Jones is the Ontario Research Chair in Postsecondary Education Policy and Measurement, Professor of Higher Education, and Dean of the Ontario Institute for Studies in Education, University of Toronto. Glen's research focuses on higher education policy, governance, academic work, and administration. He is a prolific contributor to the Canadian and international literature on higher education and a frequent public speaker and commentator on higher education issues.

Jeff Leclerc is the University Secretary at the University of Manitoba, a role he has held since 2003. In addition to a master's degree in educational administration from the University of Manitoba, Jeff has completed the Institute for Educational Management at Harvard University and holds the Chartered Director designation from McMaster's DeGroote School of Business and the Conference Board of Canada. Active in his community, he currently serves on the board of the Canadian University Boards Association, is a member of the Pension Committee for the University of Manitoba Pension Plans, and chairs the Governance Sub-Committee and is Trustee of the United Way of Winnipeg.

Sharon Li recently completed a PhD in the Higher Education Program at OISE, under the supervision of Dr. Glen Jones. Her research interest is university governance at the system and institutional level. Her doctoral dissertation studied the role of boards of trustees in public universities in China. Sharon received her BA and MA in English language and literature from Shanghai International Studies University (China). She also earned a Master of Education degree in educational leadership studies from the University of Victoria (Canada). 